\title{
PENGARUH PIJAT OKSITOSIN TERHADAP PRODUKSI ASI PADA IBU POST PARTUM DI BPM MELI R. PALEMBANG TAHUN 2018
}

\author{
Italia $^{1}$, Meli Sri Yanti ${ }^{2}$ \\ ${ }^{1}$ Dosen Program studi D-III Keperawatan STIKES Mitra Adiguna Palembang \\ Komplek Kenten Permai Blok J No 9-12 Bukit Sangkal Palembang 30114 \\ ${ }^{2}$ Mahasiswa Program Studi D-III Keperawatan STIKES Mitra Adiguna Palembang \\ Email : Italia_effendi@gmail.com
}

\begin{abstract}
Abstrak
Dalam fisiologi laktasi, prolaktin merupakan suatu hormon yang disekresi oleh grandula pituitari. Hormon ini memiliki peranan penting untuk memproduksi ASI. Permasalahan tidak lancarnya proses keluarnya ASI yang menjadi salah satu penyebab seseorang tidak dapat menyusui bayinya sehingga proses menyusui terganggu/terhambat. Selain itu, cara lain untuk mengatasi ketidaklancaran produksi ASI yaitu dengan melakukan pijat oksitosin. Tujuan penelitian untuk mengetahui pengaruh pijat oksitosin terhadap produksi ASI pada ibu post partum di BPM Meli Rosita Palembang tahun 2018. Jenis penelitian pre-eksperimen dengan rancangan penelitian one group pre test and post test design. Dalam penelitian ini menetapkan 3 orang informan yang terdiri dari 2 orang informan ibu nifas dan 1 orang informan kunci yaitu bidan. Berdasarkan analisis univariat diketahui distribusi frekuensi produksi ASI ibu sebelum dilakukan pijat oksitosin sebagian besar pada kategori kurang sebanyak 9 responden (60\%), sedangkan distribusi frekuensi produksi ASI ibu setelah dilakukan pijat oksitosin sebagian besar pada kategori baik sebanyak 13 responden (86,7\%). Ada pengaruh yang signifikan pijat oksitosin terhadap produksi ASI ibu post partum di BPM Meli Rosita Palembang Tahun 2018 dengan nilai $p$ value =0,004 $<0,05$. Saran Agar Petugas kesehatan khususnya Bidan selalu mempromosikan manfaat ASI dengan cara memberikan pelatihan atau mengajarkan kepada keluarga ibu postpartum teknik melakukan pijat oksitosin yang sangat banyak manfaatnya untuk mendukung program pemerintah tentang pemberian ASI ekslusif.
\end{abstract}

Kata kunci $\quad$ : Pijat Oksitosin, Produksi ASI

\begin{abstract}
In lactation physiology, prolactin is a hormone secreted by the pituitary grandula. This hormone has an important role to produce breast milk. The problem is that the process of breastfeeding is not smooth, which is one reason that a person cannot breastfeed the baby so that the breastfeeding process is disturbed / hampered. In addition, another way to overcome the inability of breast milk production is to do an oxytocin massage. The aim of the study was to determine the effect of oxytocin massage on breast milk production in post partum mothers in BPM Meli Rosita Palembang in 2018. This type of preexperiment research was a one group pre test and post test design study design. In this study, 3 informants consisted of 2 postpartum mothers and 1 key informant, midwife. Based on univariate analysis, it was found that the frequency distribution of mother's breast milk production before oxytocin massage was mostly in the less category as many as 9 respondents (60\%), while the frequency distribution of mother's breast milk production after oxytocin massage was mostly in the good category by 13 respondents (86.7\%). There was a significant effect of oxytocin massage on the milk production of post partum mothers in BPM Meli Rosita Palembang in 2018 with a $p$ value $=0.004<0.05$. Suggestion For Health Workers, especially Midwives, to always promote the benefits of ASI by providing training or teaching families of postpartum mothers the technique of performing oxytocin massage which is of great benefit to support government programs on exclusive breastfeeding.
\end{abstract}

Keywords: Oxytocin Massage, Breast Milk Production 


\section{PENDAHULUAN}

Air Susu Ibu (ASI) merupakan nutrisi yang paling tepat diberikan pada bayi baru lahir sampai umur 6 bulan karena pada masa tersebut usus bayi belum mampu mencerna makanan selain ASI. ASI merupakan susu segar dan steril yang diproduksi langsung oleh ibu dan dapat mengurangi gangguan gastrointestinal dibandingkan dengan makanan lain jika diminum oleh bayi. ASI juga mengandung nutrisi, hormon, unsur kekebalan, faktor pertumbuhan, anti alergi, antibodi serta anti inflamasi yang dapat mencegah terjadinya infeksi pada bayi (Purwanti dalam Ulfa, 2013).

Bagi ibu yang menyusui bayi, kelancaran ASI sangat penting untuk memenuhi kebutuhan bayi. ASI eksklusif tanpa pendamping ASI disarankan diberikan sampai dengan usia bayi menginjak usia enam bulan. Pemberian Air Susu Ibu (ASI) atau menyusui bayi dilakukan di berbagai lapisan masyarakat diseluruh dunia, karena banyak manfaat yang diperoleh dari ASI Eksklusif dan praktik menyusui selama 2 tahun (Wulandari, 2014).

Dalam rangka menurunkan angka kesakitan dan kematian, United Nation Children Fund (UNICEF) dan World Health Organization (WHO) merekomendasikan sebaiknya anak hanya disusui air susu ibu (ASI) selama paling sedikit enam bulan. makanan padat seharusnya diberikan sesudah anak berumur 6 bulan dan pemberian ASI dilanjutkan sampai anak berumur dua tahun (Kemenkes, 2014).

Selain itu pentingnya ASI juga terlihat pada acara dunia yaitu Pekan ASI sedunia Agustus 2008, The World Alliance For Breast Feeding Action (WABA) memilih tema Mother Support: Going For the Gold. Makna tema tersebut adalah suatu gerakan untuk mengajak semua orang meningkatkan dukungan kepada ibu untuk memberikan bayi-bayi mereka makanan yang berstandar emas yaitu ASI yang diberikan eksklusif selama 6 bulan pertama dan melanjutkan ASI bersama makanan pendamping ASI lainnya yang sesuai sampai bayi berusia 2 tahun atau lebih (Wulandari, 2014).

Berdasarkan data Kementrian Kesehatan Republik Indonesia (Kemenkes RI), cakupan pemberian ASI pada bayi usia 0-6 bulan dari 3.561.617 bayi, yang mendapatkan ASI hanya 1.983 .066 bayi $(55,7 \%)$. Cakupan pemberian ASI pada bayi usia 0-6 bulan tertinggi terdapat pada Provinsi Nusa Tenggara Barat sebanyak 80.412 bayi $(86,9 \%)$, sedangkan cakupan pemberian ASI pada bayi usia 0-6 bulan terendah terdapat pada Provinsi Sulawesi Utara sebanyak 9.657 bayi (263\%). Sedangkan cakupan pemberian ASI pada bayi usia 0-6 bulan di Provinsi Sumatera Selatan dari 135.874 bayi, yang mendapat ASI hanya 81.868 bayi $(60,3 \%$ ) (Kemenkes RI, 2016).

Berdasarkan data Dinas Kesehatan Kota Palembang, cakupan pemberian ASI Eksklusif pada bayi usia 0-6 bulan tahun 2015 sebanyak 9.492 bayi $(72,9 \%)$ dari 13.018 bayi, tahun 2016 cakupan pemberian ASI Ekslusif pada bayi usia 0-6 bulan mengalami penurunan 8.572 bayi $(68,5 \%)$ dari 12.509 bayi dan tahun 2017 cakupan pemberian ASI Ekslusif pada bayi usia 0-6 bulan mengalami kenaikan sebanyak 8.015 bayi $(73,2 \%)$ dari 10.937 bayi (Dinkes Kota Palembang, 2017).

Target pencapaian ASI sulit dicapai disebabkan karena salah satunya yaitu ASI tidak keluar. Permasalahan tidak lancarnya proses keluarnya ASI yang menjadi salah satu penyebab seseorang tidak dapat menyusui bayinya sehingga proses menyusui terganggu/terhambat karena itu diperlukan pendekatan pada masyarakat untuk dapat mengubah kebiasan buruk memberikan makanan pendamping ASI sebelum bayi berusia 6 bulan dan pengenalan berbagai metode yang dapat membantu ibu menyusui untuk 
memperlancar pengeluaran ASI (Arisman dalam Ulfa, 2013).

Masalah sindrom ASI kurang diakibatkan oleh kecukupan bayi akan ASI tidak terpenuhi sehingga bayi mengalami ketidakpuasan setelah menyusu, bayi sering menangis atau rewel, tinja bayi keras dan payudara terasa membesar. Namun kenyataannya, ASI sebenarnya tidak kurang sehingga terkadang timbul masalah bahwa ibu merasa ASInya tidak tercukupi dan ada keinginan untuk menambah susu formula. Kecukupan dapat dinilai dari penambahan berat badan bayi secara teratur, frekuensi BAK paling sedikit 6x sehari. Adanya mitos serta persepsi yang salah mengenai ASI dan media yang memasarkan susu formula, serta kurangnya dukungan masyarakat menjadi hal- hal yang dapat mempengaruhi ibu dalam menyusui. (Widiyanti, 2015).

Cara yang dapat dilakukan untuk meningkatkan produksi ASI adalah dengan melakukan perawatan payudara atau breast care yang bertujuan untuk melancarkan sirkulasi darah dan mencegah tersumbatnya saluran produksi ASI sehingga memperlancar pengeluaran ASI. Selain itu, cara lain untuk mengatasi ketidaklancaran produksi ASI yaitu pijat oksitosin. Pijat oksitosin adalah pemijatan pada tulang belakang yang di mulai pada tulang belakang servikal (cervical vertebrae) sampai tulang belakang torakalis dua belas, dan merupakan usaha untuk merangsang hormon prolaktin dan oksitosin setelah melahirkan.Pijatan ini berfungsi untuk meningkatkan hormon oksitosinyang dapat menenangkan ibu, sehingga ASI pun keluar dengan sendirinya. Pijat oksitosin dapat meningkatkan produksi ASI dengan cara mengurangi tersumbatnya saluran produksi ASI sehingga memperlancar pengeluaran ASI (Latifah, 2015).

Refleks oksitosin dapat dipengaruhi oleh pikiran, perasaan dan emosi ibu. Perasaan ibu dapat meningkatkan dan juga menghambat pengeluaran oksitosin. Hormon ini akan menyebabkan sel-sel otot yang mengelilingi saluran pembuat susu mengerut atau berkontraksi sehingga ASI terdorong keluar dari saluran produksi ASI dan mengalir siap untuk dihisap oleh bayi. Sehingga kemungkinan jika ibu memiliki pikiran, perasaan dan emosi yang kuat, maka akan menekan refleks oksitosin dalam menghambat dan menurunkan produksi ASI (Latifah, 2015).

Berat badan bayi merupakan salah satu indikator dari kelancaran ASI yang menurut kriteria bila ASI lancar maka berat badan bayi tidak akan turun $10 \%$ pada minggu pertama lahir bahkan bila bayi mendapatkan ASI ekslusif penurunan hanya terjadi $3-5 \%$ pada hari ke 3 dan berat badan pada minggu kedua minimal sama atau bahkan mengalami kenaikan (Bobak dalam Suryani, 2013). Sedangkan indikator kedua dimana bila bayi cukup mendapatkan ASI akan buang air besar antara 6 sampai dengan 8 kali dalam 24 jam dengan warna jernih kekuningan (Soetjiningsih dalam Suryani, 2013). Bila bayi tidak mendapatkan cukup ASI maka bayi akan sering menangis, menyusu lebih lama dari frekwensi biasanya dan ingin selalu minum ASI dengan waktu yang cukup pendek.

Berdasarkan data BPM Meli Rosita Palembang, jumlah ibu nifas tahun 2015 sebanyak 459 orang, tahun 2016 sebanyak 423 orang dan tahun 2017 sebanyak 393 orang.

Berdasarkan hasil pengamatan peneliti di BPM Meli Rosita Palembang terhadap 5 orang ibu nifas, terdapat 4 orang yang tidak mengetahui cara melakukan pijat oksitosin. Selama ini jika ada ibu nifas yang air susunya tidak keluar, bidan hanya meminta ibu untuk sesering mungkin menyusukan bayinya supaya dapat merangsang keluarnya air susu ibu. Berdasarkan hal tersebut peneliti tertarik untuk melakukan penelitian tentang pijat oksitosin terhadap kelancaran air susu ibu.

Berdasarkan latar belakang diatas, peneliti tertarik untuk melakukan penelitian dengan judul "Pengaruh Pijat Oksitosin Terhadap Produksi ASI Pada Ibu Post 
Partum di BPM Meli RositaPalembang tahun 2018".

\section{METODE PENELITIAN}

\section{Ruang Lingkup Penelitian}

Penelitian ini dilakukan terhadap semua ibu post partum yang mengalami bendungan ASI di BPM Meli Rosita Palembang dengan tujuan diketahui pengaruh pijat oksitosin terhadap produksi ASI pada ibu post partum di BPM Meli Rosita Palembang. Penelitian ini dilaksanakan pada tanggal 1 Mei - 1 Juni 2018 di BPM Meli Rosita Palembang.

Jenis penelitian pre-eksperimen dengan rancangan penelitian one group pre test and post test design adalah rancangan penelitian yang menggunakan satu kelompok subyek dengan cara melakukan pengukuran sebelum dan setelah perlakuan. Perbedaan kedua hasil pengukuran dianggap sebagai efek perlakuan (Saryono, 2011).

\section{Data dan Cara Pengumpulan Data Data}

\section{Data primer}

Dalam penelitian ini data primer diperoleh melalui hasil observasi secara langsung terhadap produksi ASI ibu post partum sebelum pemberian pijat oksitosin dan setelah pemberian pijat oksitosin pada ibu post partum.

\section{Data sekunder}

Dalam penelitian menggunakan data sekunder berupa data dari BPM Meli Rosita Palembang, buku sumber dan internet yang berkaitan dengan topik penelitian.

\section{Cara pengumpulan data}

Pada penelitian ini cara pengumpulan data dilakukan dengan mencatat hasil observasi sebelum pijat oksitosin dan sesudah pemberian pijat oksitosin terhadap produksi ASI ibu post partum.

\section{Populasi dan sampel Populasi}

Populasi pada penelitian ini adalah semua ibu post partum hari ke 2 di BPM Meli Rosita Palembang.

Sampel

Sampel pada penelitian ini adalah sebagian ibu post partum hari ke 2 yang berjumlah 15 orang.

\section{Teknik Pengambilan Sampel}

Pengambilan sampel pada penelitian ini dilakukan dengan cara non probability sampling dengan metode accidental sampling

\section{Teknik Pengumpulan Data}

Teknik pengumpulan data pada penelitian ini dilakukan dengan melakukan observasi secara langsung untuk melihat produksi ASI ibu post partum. Produksi ASI ibu post partum dinilai dengan mengobservasi tanda-tanda sebagai berikut:

1. ASI yang banyak dapat merembes keluar melalui putting

2. Setelah menyusui bayi akan tertidur / tenang selama $3-4$ jam

3. Bayi kencing lebih sering, sekitar 8 kali sehari (Delima, 2016).

Setelah mengobservasi produksi ASI ibu post partum kemudian dilakukan pijat oksitosin pada sepanjang tulang belakang (vertebrae) untuk merangsang hormon oksitosin setelah melahirkan dengan durasi 3-5 menit. Kemudian pada hari berikutnya peneliti menanyakan kembali mengenai produksi ASI ibu setelah dilakukan pijat oksitosin dan peneliti mencatat pada tabel observasi yang telah disediakan.

\section{Teknis Analisis}

Analisis data dalam penelitian ini melalui prosedur bertahap antara lain :

1. Analisis univariat

Analisis univariat bertujuan untuk menjelaskan atau mendeskripsikan karakteristik setiap variabel penelitian. Pada umumnya dalam analisis ini hanya menghasilkan distribusi frekuensi dan presentasi dari tiap variabel (Notoatmodjo, 2012). Analisa data yang 
digunakan untuk melihat distribusi frekuensi dari tiap-tiap variabel yaitu pemberian pijat oksitosin dan produksi ASI ibu post partum.

2. Analisis bivariat Analisis ini untuk mengetahui

$\mathbf{N o}$
pengaruh pijat oksitosin terhadap 1 . produksi ASI pada ibu post partum menggunakan uji statistik yang sesuai dengan tujuan penelitian, yakni uji $t$-test independent sampel dengan taraf signifikan $\alpha=0,05, \quad$ dimana $2 . \quad$ Produksi ketentuannya adalah jika nilai $\mathrm{p}$ value $>$ $\alpha(0,05)$ berarti tidak ada pengaruh dan jika $\mathrm{p}$ value $\leq \alpha(0,05)$ berarti ada pengaruh (Notoatmodjo, 2012).

Analisis ini dilakukan untuk mengetahui pijat oksitosin terhadap produksi ASI pada ibu post partum di BPM Meli Rosita menggunakan uji statistik yang sesuai dengan tujuan penelitian yaitu uji t-testindependen sample dengan taraf signifikasi $\alpha=0,05$ , dimana ketentuannya adalah jika nilai $\mathrm{p}$ value $>\alpha(0,05)$ berarti tidak ada pengaruh dan jika $\mathrm{p}$ value $\leq \alpha(0,05)$ berarti ada pengaruh.

\section{HASIL DAN PEMBAHASAN}

\section{Hasil Penelitian}

Penelitian ini dilaksanakan pada tanggal 1 Mei - 1 Juni 2018 di BPM Meli Rosita Palembang.

\section{Uji Normalitas}

Sebelum dilakukan analisis dengan uji $t$ data harus memenuhi syarat uji normalitas. Uji normalitas dalam penelitian ini digunakan uji kolmogrof-smirnov Z. Data dikatakan berdistribusi normal jika nilai signifikan (2-tailed) $>0,05$. Berikut merupakan hasil uji normalitas terhadap data dari variabel produksi ASI.
Tabel 4.1

Uji Normalitas One-Sample KolmogorovSmirnov Test

ASI

Setelah

Pijat

Oksitosn

$\begin{array}{llll}\text { Produksi } & 0,630 & 0,643 & \text { Normal }\end{array}$

ASI

Sebelum

Pijat

$0,413 \quad 0,371 \quad$ Normal Shapiro- P.Value Keterangan Wilk . 
Tabel 4.2

Distribusi Frekuensi

BerdasarkanProduksi ASI Sebelum Dilakukan Pijat Oksitosin Di BPM Meli Rosita Palembang Tahun 2018

\begin{tabular}{lcc}
\hline $\begin{array}{c}\text { Produksi ASI } \\
\text { Sebelum Pijat } \\
\text { Oksitosin }\end{array}$ & $\mathrm{N}$ & $\%$ \\
\hline Baik & 6 & 40 \\
\hline Kurang & 9 & 60 \\
\hline Total & 15 & 100 \\
\hline
\end{tabular}

Berdasarkan tabel 4.2 diatas didapatkan distribusi frekuensi produksi ASI ibu sebelum dilakukan pijat oksitosin sebagian besar pada kategori kurang sebanyak 9 responden $(60 \%)$ dan produksi ASI ibu kategori baik sebanyak 6 responden (40\%).

2. Produksi ASI Setelah Dilakukan

Pijat Oksitosin

Tabel 4.3

Distribusi Frekuensi

BerdasarkanProduksi ASI Setelah

Dilakukan Pijat Oksitosin Di BPM Meli Rosita Palembang Tahun 2018

\begin{tabular}{lcc}
\hline $\begin{array}{l}\text { Produksi ASI } \\
\begin{array}{c}\text { Setelah Pijat } \\
\text { Oksitosin }\end{array}\end{array}$ & $\mathrm{N}$ & $\%$ \\
\hline Baik & 13 & 86,7 \\
\hline Kurang & 2 & 13,3 \\
\hline Total & 15 & 100 \\
\hline
\end{tabular}

Berdasarkan tabel 4.3 diatas didapatkan distribusi frekuensi produksi ASI ibu setelah dilakukan pijat oksitosin sebagian besar pada kategori baik sebanyak 13 responden $(86,7 \%)$ dan produksi ASI ibu kategori kurang sebanyak 2 responden $(13,3 \%)$.

\section{Analisis Bivariat}

1. Perbedaan Produksi ASI Ibu Post Partum Sebelum dan Setelah Dilakukan Pijat Oksitosin

Tabel 4.4

Perbedaan Produksi ASI Ibu Post

Partum Sebelum dan Setelah Dilakukan

Pijat Oksitosin Di BPM Meli Rosita Palembang Tahun 2018

\begin{tabular}{lccc}
\hline $\begin{array}{c}\text { Produksi ASI } \\
\text { Ibu Post Parum }\end{array}$ & Mean & P value & N \\
\cline { 1 - 2 } $\begin{array}{l}\text { Sebelum Pijat } \\
\text { Oksitosin }\end{array}$ & 1,83 & & \\
\cline { 1 - 2 } $\begin{array}{l}\text { Setelah Pijat } \\
\text { Oksitosin }\end{array}$ & 2,13 & 0,004 & 15 \\
\hline
\end{tabular}

Berdasarkan tabel 4.4 dapat diketahui bahwa rata-rata sebelum dilakukan pijat oksitosin sebesar 1,83 dan rata-rata setelah dilakukan pijat oksitosin sebesar sebesar 2,13. Oleh karena nilai rata-rata produksi ASI setelah pijat oksitosin lebih besar dari pada rata-rata produksi ASI sebelum pijat oksitosin sehingga dapat dinyatakan bahwa pijat oksitosin dapat meningkatkan produksi ASI ibu post partum.

Berdasarkan hasil uji statistik menggunakan uji t-test diperoleh nilai signifikan sebesar 0,004 lebih kecil dari taraf signifikan 5\% atau ( $p$ value $=0,004<$ $0,05)$ maka dapat dinyatakan adapengaruh yang signifikan pijat oksitosin terhadap produksi ASI ibu post partum di BPM Meli Rosita Palembang Tahun 2018.

\section{Pembahasan}

Pengaruh Pijat Oksitosin Terhadap Produksi ASI Pada Ibu Post Partum

Berdasarkan analisis univariat diketahui distribusi frekuensi produksi ASI ibu sebelum dilakukan pijat oksitosin sebagian besar pada kategori kurang sebanyak 9 responden $(60 \%)$ dan produksi 
ASI ibu kategori baik sebanyak 6 responden (40\%).

Berdasarkan analisis univariat diketahui distribusi frekuensi produksi ASI ibu setelah dilakukan pijat oksitosin sebagian besar pada kategori baik sebanyak 13 responden $(86,7 \%)$ dan produksi ASI ibu kategori kurang sebanyak 2 responden $(13,3 \%)$.

Berdasarkan analisis bivariat diketahui bahwa rata-rata sebelum dilakukan pijat oksitosin sebesar 1,83 dan rata-rata setelah dilakukan pijat oksitosin sebesar sebesar 2,13. Oleh karena nilai rata-rata produksi ASI setelah pijat oksitosin lebih besar dari pada rata-rata produksi ASI sebelum pijat oksitosin sehingga dapat dinyatakan bahwa pijat oksitosin dapat meningkatkan produksi ASI ibu post partum.

Berdasarkan hasil uji statistik menggunakan uji t-test diperoleh nilai signifikan sebesar 0,004 lebih kecil dari taraf signifikan $5 \%$ atau $(p$ value $=0,004<$ $0,05)$ maka dapat dinyatakan adapengaruh yang signifikan pijat oksitosin terhadap produksi ASI ibu post partum di BPM Meli Rosita Palembang Tahun 2018.

Hasil penelitian ini sejalan dengan penelitian Wulandari (2014) yang berjudul Pengaruh Pijat Oksitosin Terhadap Pengeluaran Kolostrum Pada Ibu Post Partum Di Rumah Sakit Umum Daerah Provinsi Kepulauan Riau. Hasil penelitian ini, menunjukkan pada kelompok perlakuan rerata waktu pengeluaran Kolostrum 5.21 jam. Dalam penelitian ini pijat oksitosin dilakukan berdasarkan Standar Operasional Prosedur (SOP) yang diberikan pada ibu post partum 2 jam . Sedangkan hasil yang diperoleh pada kelompok yang tidak dilakukan pijat oksitosin (kontrol) rerata waktu pengeluaran Kolostrum 8.16 jam.Hasil perhitungan dengan analisa statistik T-Test Independent pada 15 responden kelompok perlakuan dan 15 responden kelompok kontrol didapatkan nilai $\mathrm{p}=0,006 \quad(<0,05)$. Hasil lain menunjukkan bahwa nilai $\mathrm{t}$ hitung sebesar 4.381 sedangkan nilai $\mathrm{t}$ tabel 2,048 atau $\mathrm{t}$ tabel lebih kecil dari $t$ hitung yang berarti secara statistik Ho ditolak, dengan demikian dapat disimpulkan terdapat pengaruh rerata waktu pengeluaran kolostrum antara kelompok perlakuan dan kelompok kontrol.

Hasil penelitian ini juga sejalan dengan penelitian Safitri (2015) yang berjudul pijat punggung dan percepatan pengeluaran ASI pada ibu post partum di RB As-Syifa Husada KecamatanPoncokusumo Kabupaten Malang. Hasil penelitian didapatkan hasil pada kelompok yangdiberikan perlakuan pijat punggung seluruhresponden (100\%) ASI keluar pada hari ke 2sedangkan pada kelompok yang tidak mendapatkanperlakuan pijat punggung sebanyak 6responden $(60 \%)$ ASI keluar pada hari ke 3. Sedangkan pada kelompok yangdiberikan perlakuan pijat punggung seluruhresponden sebanyak 10 orang $(100 \%)$ percepatanpengeluaran ASI dalam batas normal dankelompok yang tidak diberi perlakuan pijatpunggung 6 responden $(60 \%)$ percepatanpengeluaran ASI juga dalam batas normal. Hasil uji statistik didapatkan nilai Asymp Sig (2-tailed) = $0,029<0,05$, yang artinya ada pengaruh yang signifikan antara pijat punggungterhadap percepatan pengeluaran ASI pada ibupost partum di RB As-Syifa Husada KecamatanPoncokusumo Kabupaten Malang.

Hal ini sesuai dengan pernyataan Latifah (2015), yang menyatakan bahwa cara yang dapat dilakukan untuk meningkatkan produksi ASI adalah dengan melakukan perawatan payudara atau breast care yang bertujuan untuk melancarkan sirkulasi darah dan mencegah tersumbatnya saluran produksi ASI sehingga memperlancar pengeluaran ASI. Selain itu, cara lain untuk mengatasi ketidaklancaran produksi ASI yaitu pijat oksitosin. Pijat oksitosin adalah pemijatan pada tulang belakang yang di mulai pada tulang belakang servikal (cervical vertebrae) sampai tulang belakang torakalis dua belas, 
dan merupakan usaha untuk merangsang hormon prolaktin dan oksitosin setelah melahirkan.Pijatan ini berfungsi untuk meningkatkan hormon oksitosinyang dapat menenangkan ibu, sehingga ASI pun keluar dengan sendirinya. Pijat oksitosin dapat meningkatkan produksi ASI dengan cara mengurangi tersumbatnya saluran produksi ASI sehingga memperlancar pengeluaran ASI.

Hasil penelitian ini juga sesuai dengan pernyataan Wulandari (2014), dalam upaya pengeluaran ASI ada 2 hal yang mempengaruhi yaitu produksi dan pengeluaran. Produksi ASI dipengaruhi oleh hormon prolaktin sedangkan pengeluaran dipengaruhi oleh hormon oksitosin. Hormon oksitosin akan keluar melalui rangsangan ke puting susu melalui isapan mulut bayi atau melalui pijatan pada tulang belakang ibu bayi, dengan dilakukan pijatan pada tulang belakang ibu akan merasa tenang, rileks, meningkatkan ambang rasa nyeri dan mencintai bayinya, sehingga dengan begitu hormon oksitosin keluar dan ASI pun cepat keluar. Melalui pijatan atau rangsangan pada tulang belakang, neurotransmitter akan merangsang medulla oblongata langsung mengirim pesan ke hypothalamus di hypofise posterior untuk mengeluarkan oksitosin sehingga menyebabkan buah dada mengeluarkan air susunya. Dengan pijatan didaerah tulang belakang ini juga akan merileksasi ketegangan dan menghilangkan stress dan dengan begitu hormon oksitosoin keluar dan akan membantu pengeluaran air susu ibu, dibantu dengan isapan bayi pada puting susu pada saat segera setelah bayi lahir dengan keadaan bayi normal.

Lebih lanjut dijelaskan Wulandari (2014), bahwa dengan melakukan pemijatan pada sepanjang tulang belakang (vertebrae) sampai tulang costae kelima-keenam akan merangsang hormon prolaktin yang diproduksi oleh hipofise anterior dan oksitosin yang diproduksi oleh hipofise posterior, sehingga ASI pun otomatis dapat lebih lancar. Selain memperlancar ASI pijat oksitosin memberikan kenyamanan pada ibu nifas, mengurangi bengkak (engorgement), mengurangi sumbatan ASI, merangsang pelepasan hormon oksitosin, mempertahankan pro-duksi ASI ketika ibu dan bayi sakit.Adanya rasa nyaman yang dirasakan ibu selama pemijatan merupakan syarat keberhasilan pijat oksitosin.

Hal yang sama sesuai dengan pernyataan Perinasia dalam Wulandari (2014), yang menyatakan bahwa melalui pijatan atau rangsangan pada tulang belakang, neurotransmitter akan merangsang medulla oblongata langsung mengirim pesan ke hypothalamus di hypofise posterior untuk mengeluarkan oksitosin yang menyebabkan buah dada mengeluarkan air susunya. Dengan pijatan di daerah tulang belakang ini juga akan mereklaksasi ketegangan dan menghilangkan stress dan dengan begitu hormon oksitosin keluar dan akan membantu pengeluaran air susu ibu. Kolostrum yang menetes atau keluar merupakan tanda aktifnya reflex oksitosin.

Penelitian ini juga sejalan dengan pernyataan Mulyati dalam Wulandari (2014), menjelaskan massase/pijat merupakan salah satu terapi pendukung yang efektif untuk mengurangi ketidaknyamanan fisik serta memperbaiki gangguan mood. Pengurangan ketidaknyamanan pada ibu menyusui akan membantu lancarnya pengurangan ASI. Terjadinya peningkatan produksi ASI pada kelompok perlakuan dapat memberikan efek rileks pada ibu yang secara tidak langsung dapat menstimulasi hormone oksitosin yang dapat membantu proses kelancaran produksi ASI.Stimulasi oksitosin membuat sel-sel mioepitel di sekitar alveoli di dalam kelenjar payudara berkontraksi. Kontraksi sel-sel yang Efektifitas kombinasi menyerupai otot ini menyebabkan susu keluar melalui duktus dan masuk ke dalam sinus-sinus laktiferus. Refleks let-down dapat dirasakan sebagai sensasi kesemutan atau dapat juga ibu tidak merasakan sensasi apapun. Tanda-tanda lain let-down adalah tetesan susu dari payudara ibu dan susu menetes dari payudara lain yang tidak sedang diisap oleh bayi. 
Berdasarkan hasil penelitian dan pembahasan diatas peneliti berasumsi bahwa pijat oksitosin berpengaruh terhadap produksi ASI pada ibu post partum. Hal ini karena dengan melakukan pijat oksitosin dapat merangsang hormon prolaktin dan oksitosin serta dapat melancarkan sirkulasi darah sehingga dapat mencegah penyumbatan saluran ASI. Dengan melakukan pijat oksitosin secara rutin pada ibu post partum maka akan melancarkan produksi ASI ibu.

\section{KESIMPULAN DAN SARAN}

\section{Kesimpulan}

Berdasarkan hasil penelitian yang telah telah dilakukan di BPM Meli Rosita, AM.Keb Palembang, dapat disimpulkan sebagai berikut:

1. Berdasarkan analisis univariat diketahui distribusi frekuensi produksi ASI ibu sebelum dilakukan pijat oksitosin sebagian besar pada kategori kurang sebanyak 9 responden $(60 \%)$ dan produksi ASI ibu kategori baik sebanyak 6 responden $(40 \%)$.

2. Berdasarkan analisis univariat diketahui distribusi frekuensi produksi ASI ibu setelah dilakukan pijat oksitosin sebagian besar pada kategori baik sebanyak 13 responden $(86,7 \%)$ dan produksi ASI ibu kategori kurang sebanyak 2 responden (13,3\%).

3. Ada pengaruh yang signifikan pijat oksitosin terhadap produksi ASI ibu post partum di BPM Meli Rosita Palembang Tahun 2018 dengan nilai $\mathrm{p}$ value $=0,004$ $<0,05$.

\section{Saran}

\section{Bagi Stikes Mitra Adiguna Palembang}

Diharapkan dapat lebih melengkapi referensi seperti buku-buku sumber, majalah kesehatan, jurnal, serta bahan-bahan yang menunjang penulisan Karya Tulis Ilmiah ini guna meningkatkan mutu pendidikan, menyarankan agar mahasiswa sebelum menentukan judul sebaiknya menentukan masalah yang layak dan relevan untuk diteliti.

\section{Bagi BPM Meli Rosita}

Agar Petugas kesehatan khususnya Bidan selalu mempromosikan manfaat ASI dengan cara memberikan pelatihan atau mengajarkan kepada keluarga ibu postpartum teknik melakukan pijat oksitosin yang sangat banyak manfaatnya untuk mendukung program pemerintah tentang pemberian ASI ekslusif.

\section{Bagi Peneliti Selanjutnya}

Diharapkan peneliti selanjutnya dapat mencari alternatif lain dalam meningkatkan produksi ASI seperti melakukan breast care, teknik marmet serta dengan menggunakan metode penelitian yang berbeda sehingga penelitian tentang produksi ASI dapat terus di kembangkan.

\section{DAFTAR PUSTAKA}

BPM Meli Rosita Palembang.2017. Jumlah ibu nifas pada tahun 2015-2018.

Delima. 2016. Pengaruh Pijat Oksitosin Terhadap Peningkatan Produksi ASIIbu Menyusui Di Puskesmas Plus Mandiangin. Jurnal Ipteks Terapan. Research of Applied Science and Education V9.i4 (282-293)

Dinkes Kota Palembang. 2016. Cakupan pemberian ASI pada bayi di Kota Palembang tahun 2015

Kemenkes. 2014. Pusat data dan informasi kementrian kesehatan RI. Situasi dan Analisis ASI Eksklusif. http://www.kemenkes.go.id, diakses 15 Januari 2018

Kemenkes. 2016. Profil Kesehatan Republik Indonesia.

http://www.kemenkes.go.id, diakses 20 Januari 2018

Latifah, Juhar. 2015. Perbandingan Breast Care Dan Pijat Oksitosin Terhadap 
Produksi Asi Pada Ibu Post Partum Normal. Jurnal $D K$ Vol.3/No.1/Maret/2015

Mickey. 2016. Pijat oksitosin untuk produksi

ASI.http://nitaanitakartika32. blogspot.co.id, diakses 20 Februari 2018

Notoatmodjo, Soekidjo. 2012. Metode penelitian kesehatan. Jakarta : Rineka Cipta.

Saleha, Sitti. 2013. Asuhan Kebidanan Pada Masa Nifas. Jakarta : Salemba Medika

Suryani, Emy. 2013. Pengaruh pijat oksitosin terhadap produksi ASI ibu post partum di BPM Wilayah Kabupaten Klaten. Jurnal Terpadu Ilmu Kesehatan, Volume 2, Nomor 2, Nopember 2013, hlm.41-155

Ulfa, Raden Roro Maria. 2013. Efektivitas Pemberian Teknik Marmet Terhadap Pengeluaran Asi Pada Ibu Menyusui 0-6 Bulan Di Wilayah Kerja Puskesmas Arjasa Kabupaten Jember. Jurnal Universitas Jember.

Widiyanti. 2015. Perbedaan Antara Dilakukan Piijatan Oksitosin Dan Tidak Dilakukan Pijatan Oksitosin Terhadap Produksi Asi Pada Ibu Nifas Di Wilayah Kerja Puskesmas Ambarawa. Jurnal AKBID Ngudi Waluyo Ungaran

Wijayanti, Lilis. 2014. Pengaruh pijat oksitosin terhadap produksi ASI pada ibu post partum di Puskesmas Mergangsan Yogyakarta. Jurnal Stikes 'Aisyiyah Yogyakarta.

Wulandari. 2014. Pengaruh pijat oksitosin terhadap pengeluaran kolostrum pada ibu post partum di rumah sakit umum daerah Provinsi Kepulauan Riau. Jurnal Kesehatan, Volume V, Nomor 2,Oktober 2014, hlm 173-178 